Bull. Mater. Sci., Vol. 17, No. 6, November 1994, pp. 977-987. (C) Printed in India.

\title{
Combustion synthesis of oxide materials for nuclear waste immobilization
}

\author{
M MUTHURAMAN, N ARUL DHAS and K C PATIL \\ Department of Inorganic and Physical Chemistry, indian Institute of Science, Bangalore \\ 560012 , India
}

\begin{abstract}
Oxide materials like perovskite, zirconolite, hollandite, pyrochlore, NASICON and sphene which are used for nuclear waste immobilization have been prepared by a solution combustion process. The process involves the combustion of stoichiometric amount of corresponding metal nitrates and carbohydrazide/tetraformyl trisazine/diformyl hydrazide at $450^{\circ} \mathrm{C}$. The combustion product's have been characterized using powder $\mathrm{X}$-ray diffraction, infrared spectroscopy, and ${ }^{29} \mathrm{Si}$ MAS-NMR. The fine particle nature of the combustion derived powders has been studied using density, particle size, BET surface area measurements and scanning electron microscopy. Sintering of combustion derived powder yields $85-95 \%$ dense ceramics in the temperature range $1000^{\circ}-1300^{\circ} \mathrm{C}$.
\end{abstract}

Keywords. Combustion synthesis; SYNROC; nuclear waste immobilization.

\section{Introduction}

Ceramic oxide materials such as perovskite $\left(\mathrm{CaTiO}_{3}\right)$, zirconolite $\mathrm{CaZrTi} \mathrm{O}_{7}$, hollandite $\left(\mathrm{Ba}_{1.23} \mathrm{Al}_{2.46} \mathrm{Ti}_{5.54} \mathrm{O}_{16}\right)$, pyrochlore $\left(\mathrm{Ln}_{2} \mathrm{Zr}_{2} \mathrm{O}_{7}\right.$ and $\mathrm{Ln}_{2} \mathrm{Ti}_{2} \mathrm{O}_{7}, \mathrm{Ln}=$ rare earth metals), NASICON $\left(\mathrm{Na}_{1+x} \mathrm{Zr}_{2} \mathrm{P}_{3-x} \mathrm{Si}_{x} \mathrm{O}_{12}\right)$ and sphene $(\mathrm{CaTiSiO})$ have gained tremendous interest because of their application as the geological medium for the immobilization of radioactive wastes (Clarke 1983; Hayward and Cecchetto 1984). The stacking of the metal-oxygen polyhedra in their structure results in the formation of cavities and vacant interlayers capable of accommodating a large number of radioactive cations. The nost popular procedure employed by the nuclear power establishments during the past few decades has been to incorporate the nuclear wastes into borosilicate glasses. The serious disadvantage recognized recently is that the borosilicate glasses readily devitrify when subjected to action of water and steam at elevated temperatures and pressure (MacCarthy et al 1978). Therefore an alternative method using ceramic materials in which the radionuclides are incorporated into solid solution in an assemblage of mineralogical phases is adopted by several workers (MacCarthy and Davidson 1975; Ringwood et al 1979). Since the nuclear waste contains a variety of ions of various sizes and charge, it is difficult to incorporate all the radioactive ions in one phase. So a mixture of phases, i.e. a phase assemblage in which the phases are chemically compatible with one another, has been considered. A variety of phase assemblages have been proposed like supercalcine (MacCarthy 1976; 1979) containing scheelite, cubic zirconia, spinel, apatite, corundum and pollucite phases. Synthetic rock (SYNROC), a titanate based ceramic containing hollandite, perovskite and zirconolite phases, has been investigated (Ringwood et al 1979) for nuclear waste immobilization. Fine crystals of sphene $\left(\mathrm{CaTiSiO}_{5}\right.$, calcium titanosilicate) in an aluminosilicate glass matrix are also being 
studied as alternatives to glasses for the immobilization of nuclear wastes (Hayward and Cecchetto 1984; Hayward et al 1984).

The nuclear applications need highly reactive oxide powders in order to readily assimilate the radioactive nuclei. in their structure. The conventional methods (heat and beat, shake and bake) of preparing these materials involve firing the component oxides at elevated temperature with repeated grinding operations to ensure homogeneity. However wet chemical methods (Segal 1989) like sol-gel which have better control over homogeneity, stoichiometry and purity are increasingly used these days for the preparation of sinterable powders. In this paper, we describe the preparation of perovskite $\left(\mathrm{CaTiO}_{3}\right)$, zirconolite $\left(\mathrm{CaZrTi}_{2} \mathrm{O}_{7}\right)$, hollandite $\left(\mathrm{Ba}_{1.23} \mathrm{Al}_{2.46} \mathrm{Ti}_{5.54} \mathrm{O}_{16}\right)$ and sphene $\left(\mathrm{CaTiSiO} \mathrm{S}_{5}\right)$ by solution combustion method. The combustion derived powders have been characterized by powder pattern $X$-ray diffractometry, IR spectroscopy, BET surface area analysis, particle size measurement, ${ }^{29} \mathrm{Si}$ MAS-NMR, density measurements and scanning electron microscopy.

\section{Experimental}

\subsection{Preparation of titanyl nitrate}

Titanyl nitrate $\mathrm{TiO}\left(\mathrm{NO}_{3}\right)_{2}$ was prepared by the addition of $1: 1$ ammonia solution to titanyl chloride, $\mathrm{TiOCl}_{2}$ at $4^{\circ} \mathrm{C}$. The resulting hydroxide product was dried and dissolved in a minimum quantity of dilute $\mathrm{HNO}_{3}$ to get titanyl nitrate. The formation of titanyl nitrate was confirmed by determining the $\mathrm{Ti}$ content gravimetrically as $\mathrm{TiO}_{2}$ (Yamamura et al 1985).

\subsection{Preparation of fuels}

2.2a Preparation of carbohydrazide $(\mathrm{CH})$ : Carbohydrazide $(\mathrm{CH}) \mathrm{N}_{2} \mathrm{H}_{3} \mathrm{CON}_{2} \mathrm{H}_{3}$ was prepared as reported (Mohr et al 1953) by the hydrazinolysis of diethylcarbonate using hydrazine hydrate $(99 \%)$

$$
\mathrm{C}_{2} \mathrm{H}_{5} \mathrm{OCOOC} \mathrm{H}_{5}+2 \mathrm{~N}_{2} \mathrm{H}_{4} \cdot \mathrm{H}_{2} \mathrm{O} \rightarrow \mathrm{N}_{2} \mathrm{H}_{3} \mathrm{CON}_{2} \mathrm{H}_{3}+2 \mathrm{C}_{2} \mathrm{H}_{5} \mathrm{OH}+2 \mathrm{H}_{2} \mathrm{O} \text {. }
$$

2.2b Preparation of tetraformyl trisazine (TFTA): Tetraformyl trisazine (TFTA) $\mathrm{C}_{4} \mathrm{H}_{16} \mathrm{~N}_{6} \mathrm{O}_{2}$ was prepared by the dropwise addition of 4 mole of formaldehyde to 3 mole of hydrazine hydrate maintaining the temperature below $5^{\circ} \mathrm{C}$ as reported below (Mashima 1966).

$$
4 \mathrm{HCHO}+3 \mathrm{~N}_{2} \mathrm{H}_{4} \cdot \mathrm{H}_{2} \mathrm{O} \rightarrow \mathrm{C}_{4} \mathrm{H}_{16} \mathrm{~N}_{6} \mathrm{O}_{2}+5 \mathrm{H}_{2} \mathrm{O} \text {. }
$$

2.2c Preparation of diformyl hydrazide (DFH): $\mathrm{N}, \mathrm{N}^{\prime}$-diformyl hydrazine (DFH) $\mathrm{C}_{2} \mathrm{H}_{4} \mathrm{~N}_{2} \mathrm{O}_{2}$ was prepared by heating $1: 2$ molar ratio of hydrazine hydrate and formic acid on a steam bath overnight. The solvent was removed and ethanol was added. The solid separated was collected and dried (Ainsworth and Jones 1955)

$$
\mathrm{N}_{2} \mathrm{H}_{4} \cdot \mathrm{H}_{2} \mathrm{O}+2 \mathrm{HCOOH} \rightarrow \mathrm{C}_{2} \mathrm{H}_{4} \mathrm{~N}_{2} \mathrm{O}_{2}+3 \mathrm{H}_{2} \mathrm{O} \text {. }
$$




\subsection{Calculation of stoichiometry for the combustion reactions}

The stoichiometric composition of the redox mixtures for the combustion were calculated using the total oxidizing $(O)$ and reducing $(F)$ valencies of the components which serve as the numerical coefficient for the stoichiometric balance, so that the equivalence ratio $\Phi_{e}$ is unity (i.e. $\mathrm{O} / \mathrm{F}=1$ ) and the energy released by the combustion is maximum (Jain et al 1981). Based on the concepts of propellant chemistry the elements $\mathrm{C}, \mathrm{H}, \mathrm{Ca}, \mathrm{Ti}, \mathrm{Zr}, \mathrm{Ba}, \mathrm{Al}$ and $\mathrm{Si}$ are considered as reducing elements with valencies of $4+, 1+, 2+, 4+, 4+, 2+, 3+$ and $4+$ respectively and oxygen is an oxidizer having the valency of $2-$. The valency of nitrogen is taken as zero because of its conversion to molecular nitrogen during combustion. Accordingly the valencies of $\mathrm{Zr}\left(\mathrm{NO}_{3}\right)_{4}, \mathrm{TiO}\left(\mathrm{NO}_{3}\right)_{2}, \mathrm{Ca}\left(\mathrm{NO}_{3}\right)_{2}, \mathrm{Ba}\left(\mathrm{NO}_{3}\right)_{2}, \mathrm{Al}\left(\mathrm{NO}_{3}\right)_{3}, \mathrm{CH}_{6} \mathrm{~N}_{4} \mathrm{O}(\mathrm{CH})$, $\mathrm{C}_{4} \mathrm{H}_{16} \mathrm{~N}_{6} \mathrm{O}_{2}$ (TFTA) and $\mathrm{C}_{2} \mathrm{H}_{4} \mathrm{~N}_{2} \mathrm{O}_{2}$ (DFH) will be $20-, 10-, 10-, 10-, 15-$, $8+, 28+, 8+$, respectively. The valency of $\mathrm{SiO}_{2}$ is zero.

2.3a Synthesis of calcium titanate: Synthesis of calcium titanate $\left(\mathrm{CaTiO}_{3}\right)$ is described as a representative. Calcium nitrate $(5 \mathrm{~g})$, titanyl nitrate $(4 \mathrm{~g})$ and TFTA $(3 \mathrm{~g})$ were dissolved in minimum amount of water in a pyrex dish. The dish containing the solution was introduced into a muffle furnace maintained at $450^{\circ} \mathrm{C}$.

Table 1. Composition of the redox mixtures and the thermal phase evolution of combustion products.

\begin{tabular}{|c|c|c|c|}
\hline Composition & Compound & $\begin{array}{l}\text { Calcination } \\
\text { Temp. }\left({ }^{\circ} \mathrm{C}\right)\end{array}$ & Phases \\
\hline$A(5 g)+B(4 g)+$ TFTA $(2 \cdot 7 g)$ & $\mathrm{CaTiO}_{3}$ & - & - \\
\hline $\begin{array}{l}A(2 g)+B(3.48 g) \\
+C(3.87 g)+C H(4.76 g)\end{array}$ & $\mathrm{CaZrTi}_{2} \mathrm{O}$ & $\begin{array}{l}\text { As prepared } \\
700 \\
900 \\
1000\end{array}$ & $\begin{array}{l}\mathrm{TiO}_{2}(\mathrm{a})+\mathrm{ZrO}_{2}(\mathrm{t}) \\
\mathrm{TiO}_{2}(\mathrm{r})+\mathrm{ZOO}_{2}(\mathrm{r})+\mathrm{CaTiO}_{3} \\
+\mathrm{CaZrTi}_{2} \mathrm{O}_{3} \\
\mathrm{TiO}_{2}(\mathrm{r})+\mathrm{CaZrTi}_{2} \mathrm{O}_{7} \\
\mathrm{CaZrTi}_{2} \mathrm{O}_{7}\end{array}$ \\
\hline $\begin{array}{l}D(1 \mathrm{~g})+B(3.24 \mathrm{~g})+E(2.9 \mathrm{~g}) \\
+\mathrm{CH}(3.7 \mathrm{~g})\end{array}$ & Hollandite & $\begin{array}{l}\text { As propared } \\
1000\end{array}$ & $\begin{array}{l}\text { Amorphous } \\
\text { Hollandite }\end{array}$ \\
\hline $\begin{array}{l}A(1.84 \mathrm{~g})+\mathrm{B}(4.7 \mathrm{~g}) \\
+\mathrm{C}(1.02 \mathrm{~g})+\mathrm{D}(0.52 \mathrm{~g}) \\
+\mathrm{E}(2.48 \mathrm{~g})+\mathrm{CH}(2 \mathrm{~g}) \\
+ \text { TFTA }(2.1 \mathrm{~g})\end{array}$ & SYNROC & $\begin{array}{c}\text { As prepared } \\
1100 \text {. }\end{array}$ & $\begin{array}{l}\text { Amorphous + perovskite } \\
\text { Perơvskite }+ \text { Zirconolite }+ \text { Hollandite }\end{array}$ \\
\hline $\begin{array}{l}A(6.83 g)+B(5.43 g) \\
+F(1.47 g)+C H(6.5 g)\end{array}$ & CaTiSiOs & $\begin{array}{c}\text { As prepared } \\
400 \\
600 \\
800 \\
875 \\
950 \\
1200\end{array}$ & $\begin{array}{l}\text { Amorphous + } \mathrm{CaO}_{+} \mathrm{TiO}_{2} \text { (r) } \\
\mathrm{CaO}_{+} \mathrm{TiO}_{2}+\mathrm{CaTiO}_{3} \\
\mathrm{CaTiO}_{3}+\mathrm{CaO}+\mathrm{TiO}_{2} \\
\mathrm{CaTiSiO}_{5}+\mathrm{CaTiO}_{3}+\mathrm{SiO}_{2} \\
\mathrm{CaTiSiO}_{5}+\mathrm{CaTiO}_{3}+\mathrm{SiO}_{2} \\
\mathrm{CaTiSiO}_{5}+\mathrm{CaTiO}_{3}+\mathrm{SiO}_{2} \\
\mathrm{CaTiSiO}_{5}\end{array}$ \\
\hline $\begin{array}{l}A(4.53 g)+B(3.6 g) \\
+F(1.15 g)+\text { TFTA }(2.5 g)\end{array}$ & CaTiSiOs & 1250 & CaTiSiOs \\
\hline $\begin{array}{l}A(4.84 g)+B(3.85 g) \\
+F(1.23 g)+D F H(9 G)\end{array}$ & CaTiSiOs & 1200 & CaTiSiOs \\
\hline
\end{tabular}

$A=\mathrm{Ca}\left(\mathrm{NO}_{3}\right)_{2}, \quad \mathrm{~B}=\mathrm{TiO}\left(\mathrm{NO}_{3}\right)_{2}, \quad \mathrm{C}=\mathrm{Zr}\left(\mathrm{NO}_{3}\right)_{4}, \quad \mathrm{D}=\mathrm{Ba}\left(\mathrm{NO}_{3}\right)_{2}, \quad \mathrm{E}=\mathrm{Al}\left(\mathrm{NO}_{3}\right)_{3}, \quad F=$ Fumed $\mathrm{SiO}_{2}$, $\mathrm{CH}=$ carbohydrazide, TFTA $=$ tetraformyl trisazine, $\mathrm{DFH}=$ diformyl hydrazide. 


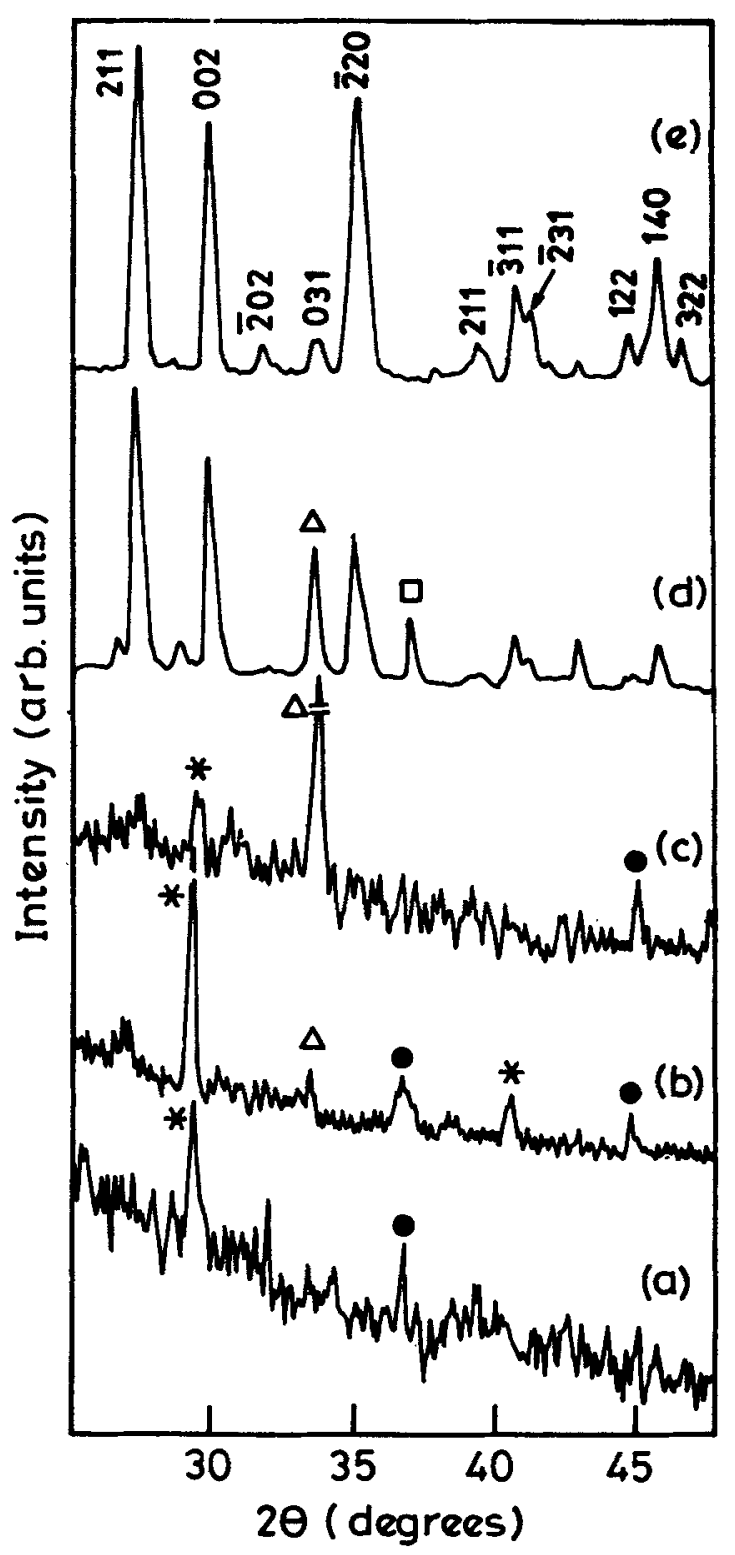

Figure 1. X-ray diffraction patterns of sphene: (a) as prepared, (b) $400^{\circ} \mathrm{C}$, (c) $600^{\circ} \mathrm{C}$, (d) $875^{\circ} \mathrm{C}$ and (e) $1200^{\circ} \mathrm{C} .\left(^{*}, \mathrm{CaO} ; O, \mathrm{TiO}_{3} ; \Delta, \mathrm{CaTiO}_{3} ; \mathrm{a}, \alpha\right.$-crystobalite).

The solution undergoes dehydration followed by decomposition with the evolution of large amount of gases (oxides of nitrogen and ammonia) and ignites to burn with a flame (flame temperature, $900 \pm 50^{\circ} \mathrm{C}$ ) yielding voluminous calcium titanate powder in less than $5 \mathrm{~min}$.

Similarly calcium zirconolite, hollandite, SYNROC and sphene (using three different fuels) were prepared using combustion process. Actual compositions of the redox mixture used for the combustion are summarized in table 1. 
Combustion synthesis of oxide materials

Table 2. The lattice parameters of the combustion products.

\begin{tabular}{|c|c|c|c|c|c|c|}
\hline Compound & a ("A) & b (A) & $c\left({ }^{\circ} A\right)$ & $\alpha(*)$ & $\left.\beta()^{\circ}\right)$ & $\left.\gamma()^{*}\right)$ \\
\hline $\mathrm{CaTiO}_{3}$ & 5.4138 & 7.6573 & $5 \cdot 3840$ & 90 & 90 & 90 \\
\hline $\mathrm{CaZrTi}_{2} \mathrm{O}_{7}$ & 12.4412 & 7.2151 & 11.50332 & 90 & $100-28$ & 90 \\
\hline Hollandite & 9.902 & 9.902 & 2.865 & 90 & 90 & 90 \\
\hline $\mathrm{CaTiSiO}_{5} / \mathrm{CH}$ & 6.975 & 8.7175 & 6.5107 & 90 & 113.22 & 90 \\
\hline CaTiSiOs/TFTA & 7.0321 & 8.7167 & 6.5508 & 90 & 113.69 & 90 \\
\hline $\mathrm{CaTiSiO}_{5} / \mathrm{DFH}$ & 7.0526 & 8.6969 & 6.5612 & 90 & 113.93 & 90 \\
\hline
\end{tabular}

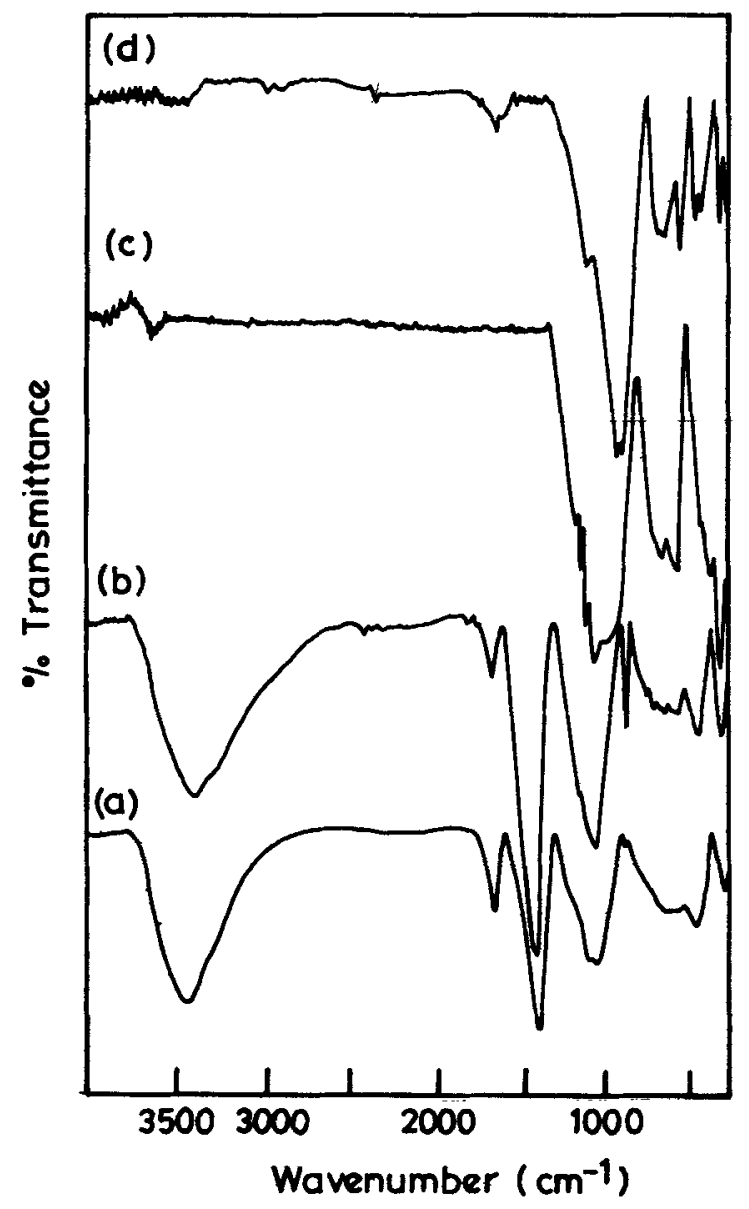

Figure 2. IR spectra of sphene; (a) as prepared, (b) $400^{\circ} \mathrm{C}$, (c) $700^{\circ} \mathrm{C}$ and (d) $1100^{\circ} \mathrm{C}$.

2.3b Product analysis: The combustion derived products have been characterized by powder XRD, recorded using Philips PW 1050/70 X-ray diffractometer with $\mathrm{Ni}$-filtered $\mathrm{Cu}-\mathrm{K} \alpha$ radiation. Lattice parameters were calculated from XRD pattern in the range of $25^{\circ} \leq 2 \theta \leq 55^{\circ}$ with a least-squares fit. The IR spectra were 
obtained using BIO-RAD SKC 3200 FT-IR Spectrometer as KBr pellets. High resolution ${ }^{2 y} \mathrm{Si}$ MAS-NMR spectra of combustion products were recorded using Bruker MSL-300 spectrometer (Switzerland, SPECTROSPIN AG). A centrifugal photo sedimentation method (Model SKC 2000 Micron photosizer) was used to determine the agglomerate particle size (i.e., Stokes diameter) and distribution of the particles (histogram). Surface areas were measured using nitrogen gas adsorption multi-point BET method (Model 2100E Accusorb, Micromeritics Instrument Corp., Norcross, GA) assuming a cross sectional area of $0.162 \mathrm{~nm}^{2}$ for the nitrogen molecule. The powder densities were measured using a pychnometer with xylene as liquid medium.

The combustion derived products were crushed and cold-pressed under $50 \mathrm{MPa}$ uniaxial pressure. The resulting green bodies have $40-50 \%$ theoretical density. Sintering of cold-pressed compacts were carried out by heating the specimens at desired temperatures in air. The bulk density of the sintered pellets were measured using Archimedes liquid displacement technique. Microstructure of sintered pellets were studied using a scanning electron microscope (SEM, Model S-150 Stereoscan, Cambridge Physical Sciences, Cambridge, UK).

\section{Results and discussion}

Formation of calcium titanate, calcium zirconolite, hollandite and calcium titanosilicates by the combustion reactions may be written as:

$$
\begin{aligned}
& 7 \mathrm{Ca}\left(\mathrm{NO}_{3}\right)_{2}+7 \mathrm{TiO}\left(\mathrm{NO}_{3}\right)_{2}+5 \mathrm{C}_{4} \mathrm{H}_{16} \mathrm{~N}_{6} \mathrm{O}_{2} \rightarrow \\
& \text { (TFTA) } \\
& 7 \mathrm{CaTiO}_{3}(\mathrm{~s})+20 \mathrm{CO}_{2}(\mathrm{~g})+40 \mathrm{H}_{2} \mathrm{O}(\mathrm{g})+29 \mathrm{~N}_{2}(\mathrm{~g}) \\
& \text { (12.7 moles of gases per mole of } \mathrm{CaTiO}_{3} \text { ) } \\
& 4 \mathrm{Ca}\left(\mathrm{NO}_{3}\right)_{2}+4 \mathrm{Zr}\left(\mathrm{NO}_{3}\right)_{4}+8 \mathrm{TiO}\left(\mathrm{NO}_{3}\right)_{2}+\underset{(\mathrm{CH})}{25 \mathrm{CH}_{6} \mathrm{~N}_{4} \mathrm{O}} \rightarrow \\
& 4 \mathrm{CaZrTi}_{2} \mathrm{O}_{7}(\mathrm{~s})+25 \mathrm{CO}_{2}(\mathrm{~g})+75 \mathrm{H}_{2} \mathrm{O}(\mathrm{g})+70 \mathrm{~N}_{2} \\
& \text { (42.5 moles of gases per mole of } \mathrm{CaZrTi}_{2} \mathrm{O}_{7} \text { ) } \\
& 2 \mathrm{Ba}\left(\mathrm{NO}_{3}\right)_{2}+4 \mathrm{Al}\left(\mathrm{NO}_{3}\right)_{3}+9 \mathrm{TiO}\left(\mathrm{NO}_{3}\right)_{2}+21 \mathrm{CH}_{6} \mathrm{~N}_{4} \mathrm{O} \rightarrow \\
& \text { (CH) } \\
& \text { Hollandite }+21 \mathrm{CO}_{2}+63 \mathrm{H}_{2} \mathrm{O}+59 \mathrm{~N}_{2} \\
& \text { ( } 88 \text { moles of gases per mole of Hollandite) } \\
& 2 \mathrm{Ca}\left(\mathrm{NO}_{3}\right)_{2}+2 \mathrm{TiO}\left(\mathrm{NO}_{3}\right)_{2}+2 \mathrm{SiO}_{2}+5 \mathrm{CH}_{6} \mathrm{~N}_{4} \mathrm{O} \rightarrow \\
& \text { (CH) } \\
& 2 \mathrm{CaTiSiO}_{5}(\mathrm{~s})+5 \mathrm{CO}_{2}(\mathrm{~g})+15 \mathrm{H}_{2} \mathrm{O}(\mathrm{g})+14 \mathrm{~N}_{2}(\mathrm{~g}) \\
& \text { (17 moles of gases per mole of } \mathrm{CaTiSiO}_{5} \text { ). }
\end{aligned}
$$

The solid product of combustion have been identified by their characteristic 


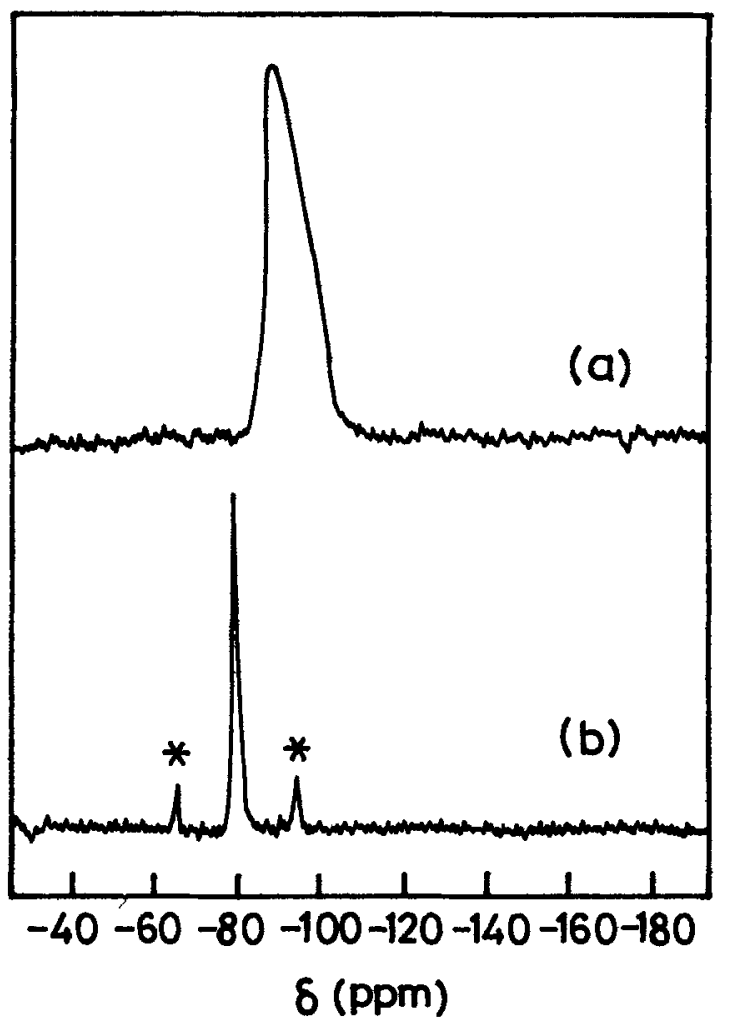

Figure 3. ${ }^{29} \mathrm{Si}$ MAS-NMR of sphene: (a) as prepared and (b) $1100^{\circ} \mathrm{C}$.

Table 3. The particulate properties of the combustion products.

\begin{tabular}{lccccl}
\hline Compound & $\begin{array}{c}\text { Powder } \\
\text { density } \\
\left(\mathrm{g} / \mathrm{cm}^{3}\right)\end{array}$ & $\begin{array}{c}\text { Surface } \\
\text { area } \\
\left(\mathrm{m}^{2} / \mathrm{g}\right)\end{array}$ & $\begin{array}{c}\text { 50\% Average } \\
\text { agglomerated } \\
\text { particle size }(\mu \mathrm{m})\end{array}$ & $\begin{array}{c}\text { Particle } \\
\text { size } \\
(\mu \mathrm{m})\end{array}$ & Ref \\
\hline $\mathrm{Ln}_{2} \mathrm{Zn}_{2} \mathrm{O}_{7}$ & 4.1 & 14 & 1.08 & 0.10 & Arul Dhas and Patil (1993) \\
$\mathrm{NASICONs}_{\mathrm{CaTiO}}$ & $2.4-2.8$ & $8-30$ & $6-13$ & - & Arul Dhas and Patil (1994) \\
$\mathrm{CaZrTi}_{2} \mathrm{O}_{7}$ & 3.46 & 21 & 0.91 & 0.08 & present study \\
Hollandite & 2.8 & 39 & 9.3 & 0.05 & present study \\
SYNROC & 3.94 & 37 & 11.5 & 0.04 & present study \\
Sphene/CH & 4.98 & 9 & 3.6 & 0.13 & present study \\
Sphene/TFTA & 2.57 & 67 & 9.0 & 0.03 & present study \\
Sphene/DFH & 2.83 & 65 & 8.3 & 0.03 & present study \\
\hline
\end{tabular}

$a=$ calculated from surface area measurement (Irani and Callis 1963).

XRD patterns (JCPDS card: $\mathrm{CaTiO}_{3} ;$ No. 22-153, $\mathrm{CaZrTi}_{2} \mathrm{O}_{7} ;$ No. 34-167, $\mathrm{Ba}_{1.23} \mathrm{Al}_{2.46} \mathrm{Ti}_{5.54} \mathrm{O}_{16}$; No. 33-133, CaTiSiO $;$; No. 25-177). Powder XRD patterns of combustion derived sphene ( $\mathrm{CH}$ process) are shown in figure 1 . The as-synthesized residue is $\mathrm{X}$-ray amorphous and shows the presence of weakly crystalline $\mathrm{CaO}$ 


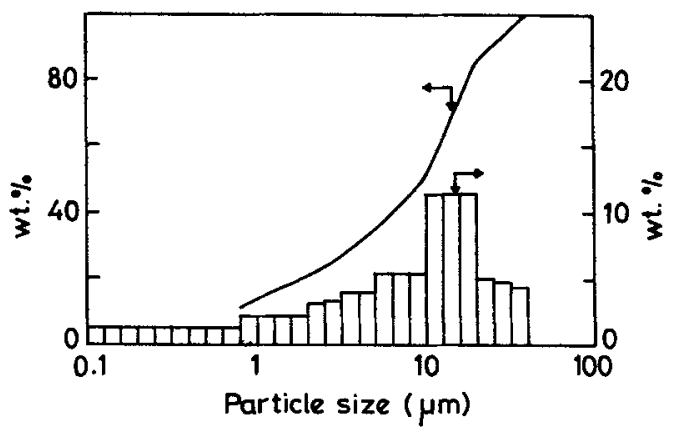

Figure 4. Particle size distribution of combustion derived zirconolite.
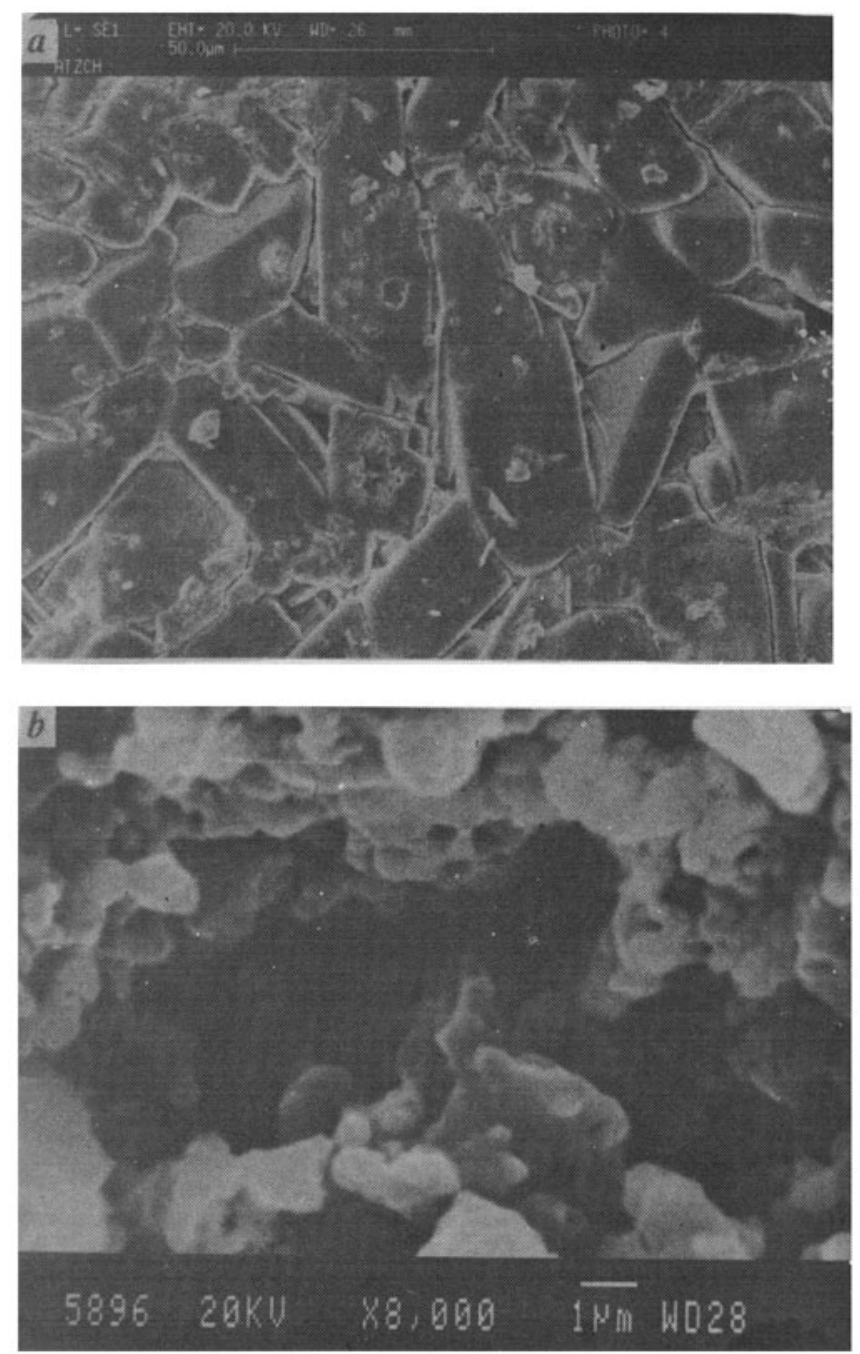

Figures 5a, b. For caption, see p. 985. 

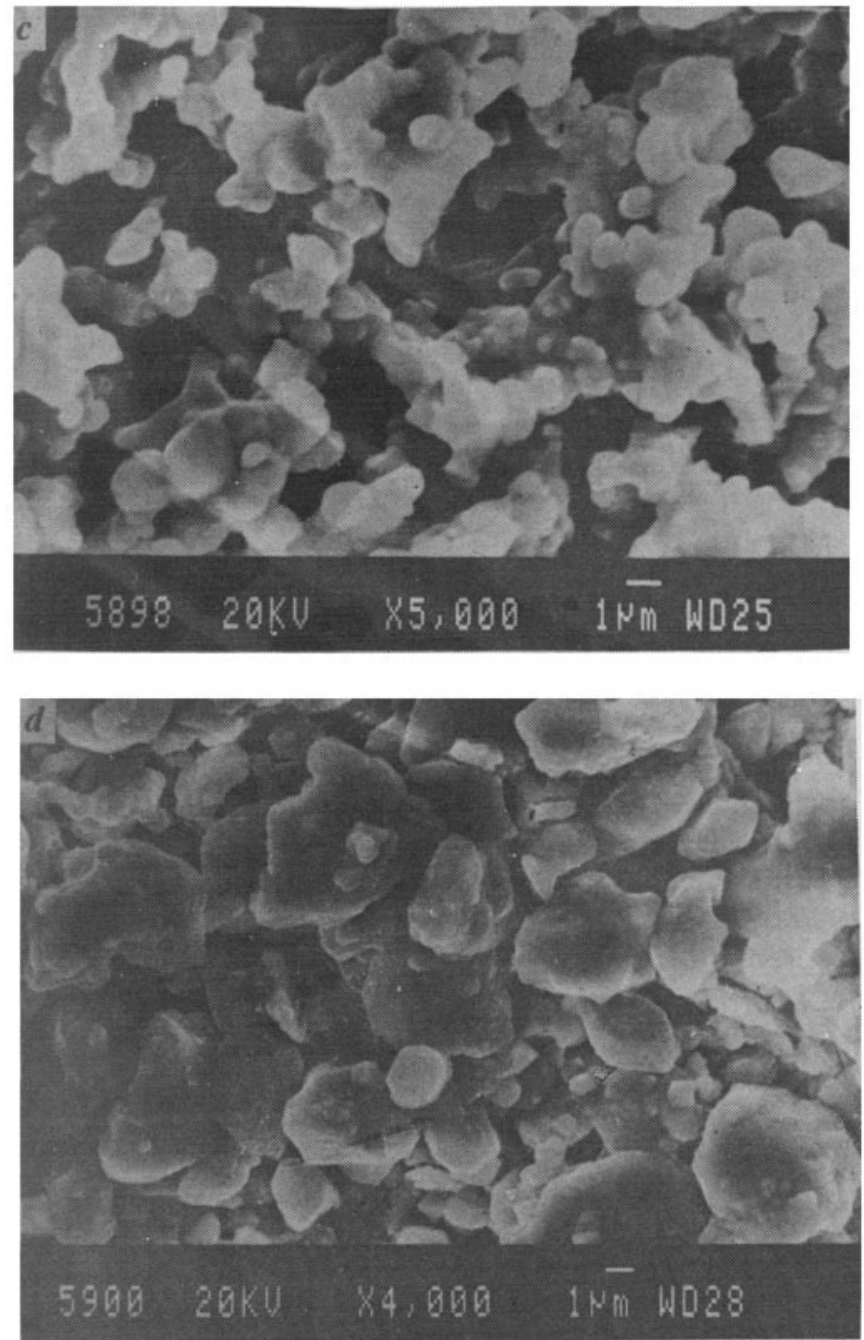

Figure 5. a-d. SEM microstructures; (a) zirconolite sintered at $1250^{\circ} \mathrm{C}$, (b) sphene sintered at $1100^{\circ} \mathrm{C}$, (c) sphene sintered at $1200^{\circ} \mathrm{C}$ and (d) sphene sintered at $1300^{\circ} \mathrm{C}$.

(figure 1a), At $600^{\circ} \mathrm{C}$ calcium titanate is the major phase along with $\mathrm{CaO}$ and $\mathrm{TiO}_{2}$ (figure 1c). On further increase in the calcination temperature $\mathrm{CaTiO}_{3}, \mathrm{CaO}$ and $\mathrm{TiO}_{2}$ appear to react with $\mathrm{SiO}_{2}$ to form $\mathrm{CaTiSiO}_{5}$. $\alpha$-crystoballite emerges out as a secondary intermediate phase (figure 1d) between $850^{\circ} \mathrm{C}$ and $1000^{\circ} \mathrm{C}$ as reported (Chen et al 1994). As the formation of $\mathrm{CaTiSiO}_{5}$ progresses the amount of $\mathrm{CaTiO}_{3}$ and $\mathrm{SiO}_{2}$ decreases. The lattice parameters calculated with a least squares-fit using XRD reflections are given in table 2. These values are in good agreement with those reported in literature.

Various intermediate phases formed during the calcination are summarized in table 1. Powder XRD pattern of as-synthesized zirconolite showed the presence of 
$\mathrm{TiO}_{2}$ (anatase) and tetragonal $\mathrm{ZrO}_{2}$. At $700^{\circ} \mathrm{C} \mathrm{TiO}_{2}, \mathrm{ZrO}_{2}$ and $\mathrm{CaTiO}_{3}$ phases are observed along with a small amount of zirconolite. On further increase in the calcination temperature $\mathrm{CaTiO}_{3}$ appears to react with $\mathrm{TiO}_{2}$ and $\mathrm{ZrO}_{2}$ to form zirconolite. The formation of single phase zirconolite occurred at $1000^{\circ} \mathrm{C}$. The relatively low formation temperature $\left(1000-1200^{\circ} \mathrm{C}\right)$ of zirconolite, hollandite and sphene indicates the high reactivity of combustion products.

The IR spectra of combustion derived sphene are shown in figure 2 . The IR spectra show the characteristic absorption of $\mathrm{SiO}_{4}$ tetrahedra at 560 and $880 \mathrm{~cm}^{-1}$ (figure 2d). The absorption band around $675 \mathrm{~cm}^{-1}$ is assigned to $\mathrm{TiO}_{6}$ octahedra (Chen and Liu 1994). It is noted that the combustion derived sphene shows broad band around 3415 and $1640 \mathrm{~cm}^{-1}$ which corresponds to $\mathrm{O}_{-H} \mathrm{H}$ stretching and bending vibrations and a sharp absorption band around $1380 \mathrm{~cm}^{-1}$ due to $\mathrm{NO}_{3}$ stretching (figure $2 \mathrm{a}$ ). The intensities of these three absorption bands decrease gradually on heating the sample to higher temperature. When the sample is heated above $600^{\circ} \mathrm{C}$ the absorption bands corresponding to the impurities completely disappear (figure $2 c)$. The occurrence of impurities, such as $\mathrm{NO}_{3}$ and $\mathrm{OH}$ in the combustion synthesized sphene could be due to the presence of fumed $\mathrm{SiO}_{2}$ in the redox mixture which reduces the flame temperature thereby giving undecomposed products.

The ${ }^{29} \mathrm{Si}$ MAS-NMR. of as prepared sphene by $\mathrm{CH}$ process shows a broad resonance at $-110 \mathrm{ppm}$ (figure $3 \mathrm{a}$ ) and corresponds to amorphous silica (Macial and Sindorf 1980). The ${ }^{29} \mathrm{Si}$ NMR of heat-treated sphene at $1100^{\circ} \mathrm{C}$ for $1 \mathrm{~h}$ shows a sharp resonance at $-80 \mathrm{ppm}$ (figure $3 \mathrm{~b}$ ) consistent with $\mathrm{SiO}_{4}$ tetrahedra (Lippmaa et al 1980). This is a low field shift compared with the resonance frequency of pure $\mathrm{SiO}_{2}$ which confirms the formation of single phase sphene.

The particulate properties of the combustion derived oxide materials used for nuclear waste immobilization are summarized in table 3 . The powder densities of the combustion products range from $60-75 \%$ of the theoretical value which indicate the porous nature of the combustion residue. The high surface area of the combustion derived products ranges from $8-67 \mathrm{~m}^{2} / \mathrm{g}$ and this could be attributed to the large amount of gases evolved during combustion [(4)-(7)] which dissipate the heat thereby inhibiting sintering of the combustion products. The $50 \%$ average agglomerated particle size of the combustion derived materials ranges from $0.9-13 \mu \mathrm{m}$. As a representation the particle size distribution of zirconolite powder is shown in figure 4 . It shows that $60 \%$ of the particles are distributed between 10 and $13 \mu \mathrm{m}$ range with the average agglomerated particle size of $9.3 \mu \mathrm{m}$.

The SEM microstructure of sintered zirconolite $\left(1250^{\circ} \mathrm{C}\right)$ is shown in figure $5 \mathrm{a}$. The SEM micrograph exhibits the presence of dense elongated grains with linear grain boundaries. The grain size vary from $40-50 \mu \mathrm{m}$. The microstructural development of sintered sphene compacts $\left(1100^{\circ}-1300^{\circ} \mathrm{C}\right)$ is illustrated in figures $5 \mathrm{~b}-\mathrm{d}$. The SEM microstructure of sintered body $\left(1100^{\circ} \mathrm{C}\right)$ shows poor densification (63\% theoretical density) and the presence of platelet particles with large pores and cavities. When the sintering temperature is increased to $1200^{\circ} \mathrm{C}$, the sintered body exhibits a network of nearly equiaxial grains with the homogeneous distribution of pores. The sintered $\left(1300^{\circ} \mathrm{C}\right)$ sphene compact shows almost pore free state with the irregular shaped grains (figure 5d). The grains are not well connected and the grain size ranges from $1-5 \mu \mathrm{m}$. The sintered body achieves more than $85 \%$ theoretical density. Sintering of sphene above $1300^{\circ} \mathrm{C}$ leads to melting of sphene which eventually reduces the sintered density. The lower sintering temperature of combustion 
derived zirconolite and sphene could be due to the large surface area and the fine particle nature of the combustion products.

\section{Conclusion}

The solution combustion process has been used successfully to prepare reactive oxide materials, which can be used for nuclear waste immobilization. The sintering of sphene and zirconolite compacts in the temperature range of $1250^{\circ}$ and $1300^{\circ} \mathrm{C}$ for $1 \mathrm{~h}$ results in a dense body (85-95\% theoretical density). SEM of the sintered compacts of sphene showed the presence of almost equiaxial grains of $1-5 \mu \mathrm{m}$ size and that of zirconolite showed the presence of elongated grains of $40-50 \mu \mathrm{m}$ size.

\section{References}

Ainsworth C and Jones R G 1955 J. Am. Chem. Soc. 77621

Arul Dhas N and Patil K C 1993 J. Mater. Chem. 31289

Arul Dhas N and Patil K C 1994 J. Mater. Chem. 4491

Chen S K and Liu H S 1994 J. Mater. Sci. 292921

Clarke D R 1983 Ann. Rev. Mater. Sci. 13191

Hayward P J and Cecchetto E V. 1984 in Scientific busis for nuclear waste management (ed) Z Lutze (New York: Elsevier) Vol. 5, p. 91

Hayward P J, Vance E R, Cann C D and Mitchell S L 1984 in Adrunces in ceramics (ed) G G Wicks and W A Ross (Ohio: American Ceramic Society, Columbus) Vol 8, p. 291

Irani R R and Callis C F 1963 in Particle size: measurement, interpretation and application (New York: John Wiley) p. 125

Jain S R, Adiga K C and Pai Verneker V R 1981 Combust. Flame 4071

Lippmaa E, Magi M, Samoson A, Engelhardt G and Grimmer A R 1980 J. Am. Chem. Soc. 1024889 MacCarthy G J 1976 Trans. Am. Nucl. Soc. 23168

MacCarthy G J 1979 in Scientific busis for nuclear waste management (ed) MacCarthy G J (New York: Plenum) Vol. 1, p. 329

MacCarthy G J and Davidson M T 1975 Am. Ceram. Soc. Bull. 54782

MacCarthy G J, White W B, Rustum Roy, Scheetz B E, Komarneni S, Smith D K and Roy D M 1978 Nature (London) 273216

Macial G and Sindorf D $1980 \mathrm{~J}$. Am. Chem. Soc. 1027606

Mashima M 1966 Bull. Chem. Soc. Jpn. 39504

Mohr E B, Brezinki J J and Audrieth L F 1953 Inorg. Synth 432

Ringwood A E, Kesson S E, Ware N G, Hibberson W and Major A 1979 Nature (London) 278219

Segal D 1989 Chemical synthesis of advanced ceramic materials (Cambridge: Cambridge University Press)

Yamamura H, Tanada M, Tanada H, Shirasaki S and Moriyoshi Y 1985 Ceram. Int. 1117 